\title{
The Phonological Interference of Students' First Language in Pronouncing English Sounds (A Case Study on Buginese and Makassarese Students)
}

\author{
Dian Hera Utami \\ dianherautami@gmail.com
}

\author{
Basri Wello \\ mbasriwello6@gmail.com
}

Haryanto Atmowardoyo

aharyanto_fbsunm@yahoo.co.id

State University of Makassar, Indonesia

\begin{abstract}
The study indicates the phonological interferences experienced by the Buginese and Makasserese students in pronouncing English sounds and the factors affect pronunciation interference of Buginese and Makasserese students in pronouncing English sounds. The respondents were eight university students majoring English Department. They are four Buginese students which their L1 is Buginese and four Makassarese students which their L1 is Makassarese. This research was conducted through a case study design. The instruments used to collect the data were oral test by reading three different texts and interview about students' problems in pronouncing English sounds. The result of data analysis showed that there is 46 kinds manner of articulation that the students made when they produced English sounds; 32 vowels and 14 consonants. The data also showed that the main factor that influences the students while pronouncing English words is interlanguage transfer. In conclusion, both Buginese and Makassarese students similar negative transfer when pronouncing English words. The implication of this research can be expected upon teaching and learning process. The students should put more awareness toward the L1 interference in pronouncing English vowels and consonants and drill more the correct pronunciation. The study also suggests that the teachers should give an extra attention to this problem. The teacher is expected to be able to help the students to reduce the mispronounced words. The study also has some contributions to the language field where teachers/lecturers need to take a special attention of this phenomenon.
\end{abstract}

Keywords: Phonology, Interference, First Language

\section{INTRODUCTION}

The number of languages or language variations in Indonesia makes Indonesian as bilingual or even multilingual. The influence of the variation of language causes the tendency of one language to another. The interference in communication is usually caused by the interaction of these languages. Selinker (1972) states that when the speakers or language learner s use a second language then their habits will affect the target language. 
Language learners have their psychological structure hidden in their brain which is automatically active, so that pronunciation often occurs when a speaker or learner use the second language.

The lingual factor is one of the main causes of the appearance of students' first language interference. Chaer and Agustina (1995) add if the errors are caused by the interference where the first language deviates from the elements of the second language. In addition, Weinrich (1968) describes interference as a disturbance in language systems of the bilinguals.

Interference is also called language transfer or cross-linguistic influence, though these terms refer to a broader phenomenon is often used interchangeably. Transfer suggests a practice in which some kind of influence is essential for it to happen (Odlin: 2005). In simple terms, it is a process in which the learner tends to assume that the system of L2 is more or less the same as his L1 until he discovers that it is not (Ringbom, 1987). In other words, one's native language (or another previously acquired language) influences the language being studied, with the result being one of transfer. Such influence may be called positive when it facilitates the learning of a skill, given similarities between two languages, or negative when a skill transferred from the L1 results in a production that is different from target language expectations (Noor, 1994).

Dulay and Krashen (1982) stated that interference is an automatic transfer that occurs due to custom, overlapping between the first language of the target language. The target language deviation is a result of their familiarity with more than one language. They distinguish interference into two parts, namely psychological and sociolinguistics. Psychology shows the influence of old habits, while sociolinguistics shows the interaction of language when two language communities are in contact. Kridalaksana (1985) mentioned there are difficulties that the students faced in mastering a second language due to the interference, which is influenced by old habits, familiar with the mother tongue, and the interaction of two languages in society. Interference can occur in phonological, grammatical, lexical, and semantic systems.

In South Sulawesi, people may develop bilingualism because most of people can speak by using Buginese language and Makassarese language, Buginese and Indonesian, Buginese and English, Makasserese and Indonesian, Makassarese and English, and others. There are even people who multilingual because they can speak Buginese and Makassarese as well as English, and so on. Negative transfer of Buginese and Makassarese towards pronouncing English sounds a lot going on. For example, if the Buginese speaker pronounces sound $/ \theta /$ /f/, /z/, / / /, and so forth. The speakers pronounce word 'think' / $\theta \mathrm{rgk} /$ become /ting/, 'of'/əv/ become /op/, 'all'/o:1/ become /al/, 'zoom'/zu:m/ become /sum/, shy /Jai/ become /sai/, and so forth.

In a line with the discussion are highlighted in this research is interference of Buginese and Makassarese language in speaking English. Phonological interference of first language made by the students in speaking English is seen by the researcher as an urgent problem to be solved. The cause of the problem is the inappropriate phonology made by the students when they produce English sounds. 
Based on the previous illustration, the objective of this research was to find out:

1. The phonological interferences made by the Buginese and Makasserese students in pronouncing English sounds.

2. The factor affects pronunciation interference of Buginese and Makasserese students in pronouncing English sounds.

\section{REVIEW OF LITERATURE}

\section{Previous Related Studies}

Many researchers have been conducting studies related to the interference of L1 to L2. Weda and Sakti (2017) discussed and analyzed the effects of formal instruction on the acquisition of English short vowels of students of English Literature Study Program Faculty of Languages and Literature Universitas Negeri Makassar, Indonesia. Their research found that the formal instruction relates significantly to the improvement of students"e acquisition of English short vowels. The also found that the majority of the students transcribed the short vowels as long vowels, e.g., a becomes e: as in docter; I becomes i as in sit. Conspicuously, the Indonesian learners' problems in pronouncing short vowels: I, e, $\mathfrak{x}, \Lambda, \mathrm{p}$, and $\mho$ need more attention from the teachers and language practitioners, especially in countries where English becomes a compulsory subject at schools and universities and also taught as a Foreign Language (FL).

A research conducted by Nada (2012) related to the cause of errors made by Iraq EFL students related to L1. It is revealed that most of the students rely on or depend on their mother tongue when they speaking or expressing their ideas. The main cause of this problem is a grammatical error. Thus, it shows the influence of Arabic on students' writing of English.

Akhyaruddin (2011) conducted a research to analyze the interference of Bugisnese language in learning of Indonesian language at SD Kabupaten Tanjung Jabung Timur, Jambi. The data is an oral language which is spoken by the students who the mother language is Buginese. His research found that there are three types of the interference which are occurred in students' conversation: phonological, morphological, and syntax interferences. The interference of Buginese does not occur consciously, but it occurs because there is an effect from daily life so that the element of Buginese words or sentences is still carried in the communication at the school.

Bennui (2008) conducted a research to analyze the problems that Thai EFL students faced with transfer phenomena in the learning process while trying to communicate their ideas. The research revealed that there was a significant level of L1 interference that represents more negative transfers than positive transfers in students' written English. In addition, the results show the different types of errors such as the use of vocabulary, phrases, clauses and sentence structure, as well as the language style of paragraph writing. It can be concluded that at the end of the study it is possible to identify that all aspects of L1 interference should be seriously considered by teachers in writing courses so that negative 
transfers will be reduced and positive transfers will appear and become a useful tool for students when analyzing the structures both structures.

\section{METHOD}

This research was a qualitative case study. This research aimed to find out what phonological interferences occurred by the Buginese and Makasserese students in pronouncing English sounds and the factors cause it. The data are taken from eight sources, they are four Buginese students and four Makassarese students of English Education Department of Muhammadiyah University of Makassar. The students had been chosen based on some considerations.

Two kinds of instruments were used to collect the data, namely oral test and interview. Oral test was used by reading three different texts. The interview was used to get the data concern with students' problems to the English pronunciation. In this research, audio recording used to collect data. The data gathered was analyzed by using Ellis' (1997) steps to find the students' errors when they pronouncing English sounds. The steps were collect the sample of this research, identify the error, describe the errors, explain the errors, and evaluate the errors.

\section{FINDINGS AND DISCUSSION}

\section{The Phonological Interferences Occurred by the Buginese and Makasserese Students in Pronouncing English Sounds}

The researcher found that there are 4 Bugisnese students and 4 Makassarese students made some errors on the test that the researcher gave. Of the 8 students, the researcher found that there is 46 kinds manner of articulation that the students made when they produced English sounds, consist of 32 vowels and 14 consonants.

The most frequent error that the Buginese and Makassarese students made when they pronounced word "of". All of the students made an error on it. Then, there are 7 students made an error when they pronounced word "she", and "thus". The last is there are 6 students made an error when they pronounced word "especially" and "equal".

Table 1. Modification of English Vowels

\begin{tabular}{|c|c|c|c|}
\hline No. & English vowels & $\begin{array}{c}\text { Modification } \\
\text { (Buginese and Makassarese) }\end{array}$ & Words \\
\hline \multirow[t]{2}{*}{1.} & \multirow[t]{2}{*}{$\begin{array}{l}/ \mathrm{p} / \text { open back } \\
\text { rounded vowel }\end{array}$} & /o/ open-mid back rounded vowel & $\begin{array}{l}\text { Of, nonsense, honour, } \\
\text { involved, blond, }\end{array}$ \\
\hline & & /a/ open-low front unfounded vowel & Was, parliaments \\
\hline \multirow[t]{2}{*}{2.} & \multirow{2}{*}{$\begin{array}{l}/ \mathrm{I} / \\
\text { near-close near- } \\
\text { front unrounded } \\
\text { vowel }\end{array}$} & /১/ mid-central vowel & $\begin{array}{l}\text { Privet, inflicted, } \\
\text { wanted, behind, } \\
\text { indigenous }\end{array}$ \\
\hline & & $\begin{array}{l}\text { /e/ close-mid front unrounded } \\
\text { vowel }\end{array}$ & $\begin{array}{l}\text { Descendants, } \\
\text { especially, pretended, } \\
\text { indigenous, }\end{array}$ \\
\hline
\end{tabular}




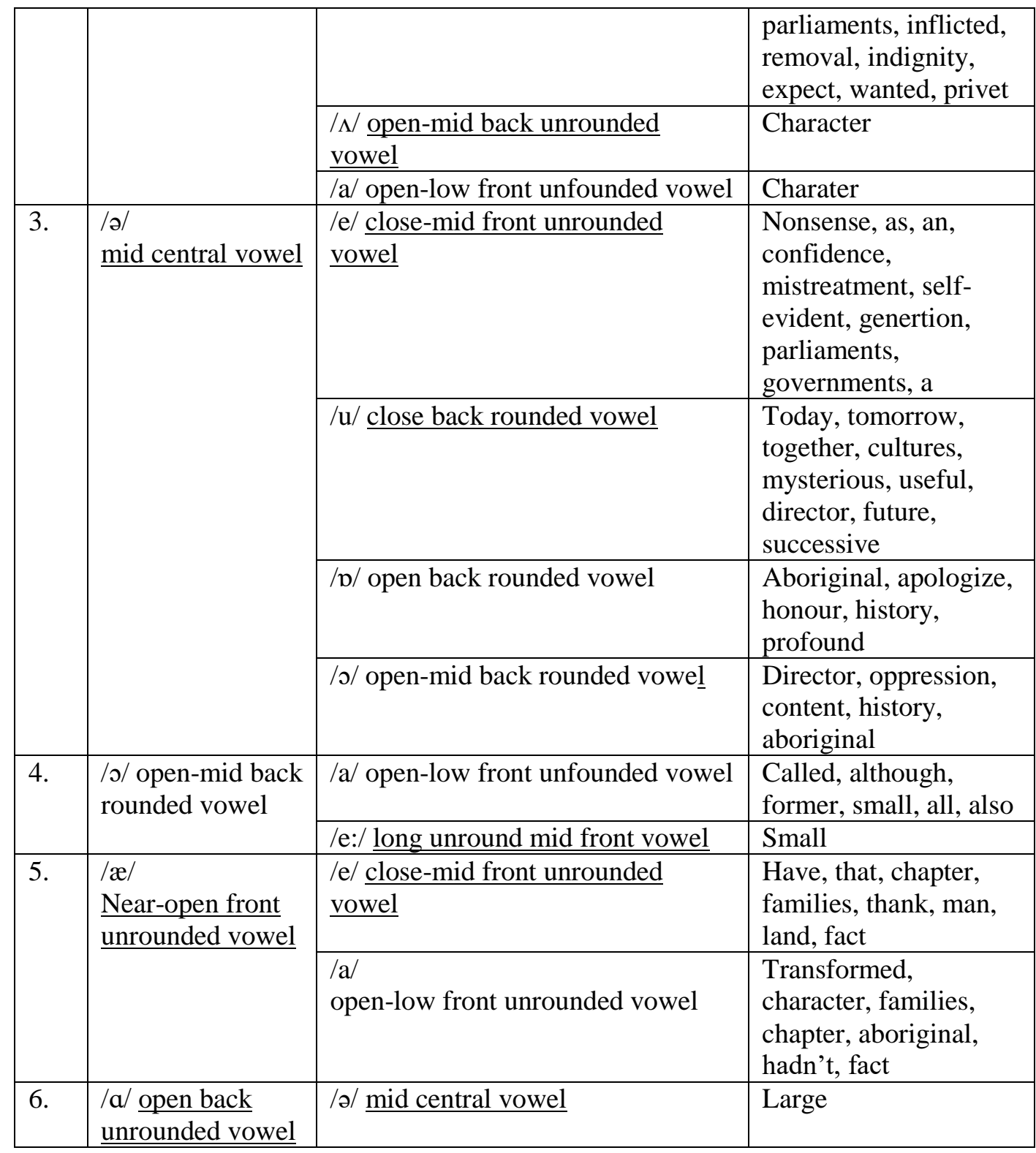

Table 2. Modification of English Vowels

\begin{tabular}{|c|c|c|c|}
\hline No. & English vowels & $\begin{array}{c}\text { Modification } \\
\text { (Buginese and Makassarese) }\end{array}$ & Words \\
\hline \multirow[t]{3}{*}{7.} & \multirow{3}{*}{$\begin{array}{l}\text { le/ } \\
\text { close-mid front } \\
\underline{\text { unrounded vowel }}\end{array}$} & $\begin{array}{l}/ \Lambda / \text { Open-mid back unrounded } \\
\text { vowel }\end{array}$ & Difficulties, strait \\
\hline & & /i:/ long unround high front vowel & $\begin{array}{l}\text { Men, neck, met, } \\
\text { fellow }\end{array}$ \\
\hline & & /J/ open-mid back rounded vowel & Fellow \\
\hline
\end{tabular}




\begin{tabular}{|c|c|c|c|}
\hline & & /a/mid central vowel & Descendants, content \\
\hline \multirow[t]{2}{*}{8.} & \multirow[t]{2}{*}{$\begin{array}{l}/ \Lambda / \\
\text { open-mid back } \\
\underline{\text { unrounded vowel }}\end{array}$} & $/ \mathrm{u} / \mathrm{close}$ back rounded vowel & $\begin{array}{l}\text { Son, suffering, thus, } \\
\text { injustice, cultures, } \\
\text { such }\end{array}$ \\
\hline & & $\begin{array}{l}\text { /o/ } \\
\text { open-mid back rounded vowel }\end{array}$ & $\begin{array}{l}\text { Governments, } \\
\text { discover, brotherhood, } \\
\text { colour, sons, country, } \\
\text { mothers, culture, one }\end{array}$ \\
\hline \multirow[t]{2}{*}{9.} & \multirow[t]{2}{*}{$\begin{array}{l}\text { /a/ open-low front } \\
\text { unfounded vowel }\end{array}$} & /s/ open-mid back rounded vowel & $\begin{array}{l}\text { Out, down, now, } \\
\text { found, about }\end{array}$ \\
\hline & & $\begin{array}{l}\text { /e/ close-mid front unrounded } \\
\text { vowel }\end{array}$ & Character \\
\hline \multirow[t]{3}{*}{10.} & \multirow{3}{*}{$\begin{array}{l}\text { li:/ } \\
\text { long unround } \\
\text { high front vowel }\end{array}$} & $\overline{\text { /e:/ long unround mid front vowel }}$ & $\begin{array}{l}\text { Equal, secret, deeply, } \\
\text { mistreatment }\end{array}$ \\
\hline & & $\begin{array}{l}\text { /3:/ long unrounded open-mid } \\
\text { central vowel }\end{array}$ & Heat \\
\hline & & $/ \mathrm{a} /$ & Descendants, content \\
\hline \multirow[t]{3}{*}{11.} & \multirow{3}{*}{$\begin{array}{l}\text { /3:/ } \\
\text { long unrounded } \\
\text { open-mid central } \\
\text { vowel }\end{array}$} & /i:/ long unround high front vowel & Firm, her \\
\hline & & $\begin{array}{l}/ \Lambda: / \text { long open-mid back unrounded } \\
\text { vowel }\end{array}$ & Hurt \\
\hline & & /u:/ long round high back vowel & Turn \\
\hline \multirow[t]{2}{*}{12.} & \multirow{2}{*}{$\begin{array}{l}\text { lu:/ } \\
\text { long round high } \\
\text { back vowel }\end{array}$} & $\begin{array}{l}\text { /o:/ long round open-mid back } \\
\text { vowel }\end{array}$ & Rooted, move \\
\hline & & / p:/ long open back rounded vowel & Truths \\
\hline
\end{tabular}

The most frequent errors of modification vowel sounds that the Buginese and Makassarese students made are the change of near-close near-front unrounded vowel $/ \mathrm{I} /$ to mid-central vowel /ə/, close-mid front unrounded vowel /e/, open-mid back unrounded vowel $/ \mathrm{N} /$, and open-low front unrounded vowel /a/. Then, mid-central vowel /ə/ change to close-mid front unrounded vowel /e/, close back rounded vowel /u/, pen back rounded vowel /p/, and openmid back rounded vowel $/ \mathrm{\rho} /$.

Table 3. Modification of English Consonants

\begin{tabular}{|c|c|c|c|}
\hline No. & $\begin{array}{c}\text { English } \\
\text { consonants } \\
\end{array}$ & $\begin{array}{c}\text { Modification } \\
\text { (Buginese and Makassarese) }\end{array}$ & Words \\
\hline 1. & $\begin{array}{l}\text { /3/ voiced palato } \\
\text { alveolar fricatives }\end{array}$ & /s/ voiceless alveolar fricative & Usual \\
\hline \multirow[t]{2}{*}{2.} & \multirow{2}{*}{$\begin{array}{l}/ \mathrm{J} / \text { voiceless } \\
\text { palato-alveolar } \\
\text { fricative }\end{array}$} & /s/ voiceless alveolar fricative & She, especially \\
\hline & & $/ \mathrm{t} \int /$ voiceless palatal affricatives & Moustache \\
\hline 3. & $\begin{array}{l}/ \theta / \text { voiceless } \\
\text { dental fricatives }\end{array}$ & /t/ voiceless alveolar plosive & $\begin{array}{l}\text { Truths, anything, thin, } \\
\text { everything, nothing, } \\
\text { think }\end{array}$ \\
\hline 4. & /t/ voiceless & $/ \theta /$ voiceless dental fricatives & Righting \\
\hline
\end{tabular}


ELT Worldwide Vol 4 No 2 (2017)

Utami, Wello, Atmowardoyo: The Phonological Interference of Students' ...

\begin{tabular}{|c|c|c|c|}
\hline & alveolar plosive & & \\
\hline \multirow[t]{2}{*}{5.} & \multirow{2}{*}{$\begin{array}{l}/ \mathrm{d} 3 / \text { voiced } \\
\text { palatal } \\
\text { affricatives }\end{array}$} & /k/ voiceless velar plosive & Page \\
\hline & & /g/ voiced velar plosive & $\begin{array}{l}\text { Apologise, generation, } \\
\text { page, aboriginal }\end{array}$ \\
\hline 6. & /n/ alveolar nasal & $/ \mathrm{y} /$ voiced velar nasal & $\begin{array}{l}\text { Strange, inflicted, } \\
\text { down, and, thin }\end{array}$ \\
\hline 7. & $\begin{array}{l}\text { /v/ voiced } \\
\text { labiodental } \\
\text { fricatives }\end{array}$ & /f/ Voiceless labiodental fricatives & Very \\
\hline \multirow[t]{3}{*}{8.} & \multirow{3}{*}{$\begin{array}{l}\mathrm{t} f / \text { voiceless } \\
\text { palatal } \\
\text { affricatives }\end{array}$} & /t/ voiceless alveolar plosive & Cultures, future \\
\hline & & /s/ voiceless alveolar fricative & Such \\
\hline & & /k/ voiceless velar plosive & Such, chapter \\
\hline 9. & $\begin{array}{l}\text { /z/ voiced } \\
\text { alveolar fricative }\end{array}$ & /s/ voiceless alveolar fricative & This, as, has, these \\
\hline 10. & $\begin{array}{l}/ \mathrm{m} / \text { voiced } \\
\text { alveolar nasal }\end{array}$ & /n/ alveolar nasal & Confidence \\
\hline
\end{tabular}

The most frequent errors of modification consonant sound that the Buginese and Makassarese students made is the change of voiceless palatal affricatives / $\mathrm{t} /$ to voiceless alveolar plosive /t/, voiceless alveolar fricative /s/, and voiceless velar plosive $/ \mathrm{k} /$.

Factor affects pronunciation interference of Buginese and Makasserese students in speaking English.

The researcher found that there are three main factors that influence the students when pronounced the English words. They are, (1) The interlingual factor, (2) The overextension of analogy, and (3) Transfer of structure. From those three causes, the researcher can conclude that the Buginese and Makassarese students may realize that English sounds and their L1 sounds must be distinguished when they speak in foreign language. Some of the students have known about the rules but sometimes they forgot to apply it when produced the English sounds. It might be because the interference of L1, the limitation of memory, psychological problem, and or do not understand the material of the subject.

\section{CONCLUSION AND SUGGESTIONS}

All Buginese students and Makassarese students made some errors on pronouncing English sounds. It was found that there are 46 kinds of similar articulation mistakes made by both Buginese and Makassarese students. It consists of 32 consonants and 14 vowels.

There is no significant difference between Buginese and Makassarese students on pronounce English sounds. Generally, they have similar problems in pronouncing English sounds. The students may realize that English sounds and their L1 sounds must be distinguished when they speak in foreign language. Some of the students have known about the rules but sometimes they forgot to applied it when produced the English sounds. It might be because the interference of L1, the limitation of memory, psychological problem, and or do not understand the material of the subject. 
The implication of this research can be expected upon teaching and learning process. The teachers should give attention more about this problem. In other that, the students can reduce the mispronouncing when they produce English sounds. This research also suggests that the students should put more awareness toward the L1 interference in pronouncing English vowels and consonant and drill more the correct pronunciation. The study also indicates some remarkable contributions to the language field where teachers/lecturers need to take a special attention of this phenomenon.

\section{REFERENCES}

Akhyaruddin. 2011. Studi Kasus Interferensi Bahasa Bugis dalam Pembelajaran Bahasa Indonesia di Sekolah Dasar Tanjung Jabung Timur, Pena Vol. 1 No. 1 Desember 2011: 29-39 ISSN 2089-3973. FKIP Universitas Jambi.

Bennui, P. 2008. A study of L1 interference in the writing of Thai EFL Students, Malaysian Journal of ELT.Research 4.Thaksin (Thailand): University of Thailand.

Chaer, A., \& Agustina, L. 2010. Sociolinguistik: Perkenalan Awal. Jakarta: Rineka Cipta.

Dulay, H., Burt, M. \& Krashen, S., 1982. Language Two. Oxford: Oxford University Press.

Ellis, R. 1997. Second Language Acquisition Oxford: Oxford University Press.

Kridalaksana, H. 1985. Tata Bahasa Deskriptif Bahasa Indonesia: Sintaksis. Jakarta: Pusat Pembinaan dan Pengembangan Bahasa Departemen Pendidikan dan Kebudayaan.

Nada, S.A.R. 2012. The Effect of EFL Learners' Mother Tongue on Their Writings in English: An Error Analysis Study," Iraq Journal of the College of Arts. Basrah (Iraq): University of Basrah.

Noor, H. 1994. Some Implications of the Role of the Mother Tongue in Second Language Acquisition. Linguistica Communicatio, 6(1-2), 97-106.

Odlin, T. 2005. Crosslinguistic Influence and Conceptual Transfer: What are the Concepts. Annual Review of Applied Linguistics Vol. 25. Cambridge University Press.

Ringbom, H. 1987. The Role of the First Language in Foreign Language Learning. Clevedon: Multilingual Matters.

Selinker, L. 1972. “Interlanguage”. Journal International Review of Applied Linguistics.

Weda, Sukardi \& Sakti, A.E.F. (2017). The Effect of Formal Instruction on the Acquisition of English Short Vowels. International Journal of Science and Research (IJSR), Volume 6 Issue 5, May 2017.

Weinreich, U. 1968. Languages in Contact. The Hague: Mouton. 